\title{
Behavioral profile, lifestyle and social skills in Portuguese adolescents
}

\author{
Clarisse Magalhães ${ }^{1 *}$, Maria Fátima Ribeiro ${ }^{1}$, Maria Raquel Esteves ${ }^{1}$, Luísa Aires ${ }^{2,3,4}$, Sara Lima ${ }^{1}$, Gustavo Silva ${ }^{2,5}$, \\ Assunção Nogueira', Teresa Herdeiro ${ }^{1,6}$ and Susana Pedras ${ }^{1}$
}

\begin{abstract}
Background: Seventy percent of premature deaths in adults are due to behaviors initiated during adolescence. Therefore, it is essential to promote individual and social behaviors that educate adolescents in the ability to make healthy choices. Accordingly, the main goals of this study were to characterize Lifestyles and Social Skills, as well as identify homogeneous subgroups, in a sample of Portuguese adolescents.

Methods: A cross-sectional study was conducted, including 1008 adolescents attending the 7th to the 9th grades of five middle schools from the Tâmega and Sousa regions of Portugal, and using the My Lifestyle Questionnaire and the Social Skills Inventory. To establish a profile of the participants, a Cluster Analysis (K-means) was performed, and the Jaccard coefficient was used to assess the stability of the solution found.

Results: From the total sample, 556 adolescents with a mean age of 13.43 years ( $S D=1.1)$ were included in the analysis. The majority of the sample presented a healthy lifestyle (72.26\%) and $50.7 \%$ of the adolescents had a highly elaborated repertoire of Social Skills. Moreover, three clusters were found. Cluster $1(n=92)$ showed a less elaborate repertoire of Social Skills and was designated as the "Adjusted". Cluster $2(n=115)$ comprised adolescents with a good repertoire of Social Skills and was named the "Sociable". Cluster $3(n=258)$ was composed of adolescents with a highly elaborate repertoire of Social Skills and the best Lifestyle indicators and was named the "Healthy".

Conclusions: The group of adolescents in the cluster called the "Sociable" needs to be included in health education and Social Skills programs. Nutrition and Monitored Safety behaviors reveal low values and, therefore, present a greater need for awareness, sensitization, and intervention in the school context. For this reason, the promotion of a healthy lifestyle should be part of the academic curriculum and transversal to all academic disciplines.
\end{abstract}

Keywords: Behavioral profile, Lifestyle, Social skills, Adolescents

\section{Background}

The leading causes of illness and deaths among young adults are largely preventable [1] and studies have shown that about $70 \%$ of premature adult deaths are due to behaviors initiated during adolescence (e.g. tobacco use, drugs, and reckless driving) [2]. Therefore, any effort to understand and improve the knowledge about health

\footnotetext{
* Correspondence: clarisse.magalhaes@ipsn.cespu.pt

'CESPU, Institute of Research and Advanced Training in Health Sciences and Technologies, Rua Central de Gandra, 1317, 4585-116 Gandra, PRD, Portugal Full list of author information is available at the end of the article
}

and risk behaviors in adolescents is warranted and welcomed.

In adolescence, the most studied lifestyle behaviors are nutrition and physical activity. These two have shown to be commonly associated, mainly because obesity is a chronic disease related to an unbalanced diet and low levels of physical activity [3-5], with a worrying prevalence in Portugal, especially in the group of adolescents between 10 and 12 years old, where $23.1 \%$ are overweight and $9.6 \%$ are obese [6].

(c) The Author(s). 2021 Open Access This article is licensed under a Creative Commons Attribution 4.0 International License, which permits use, sharing, adaptation, distribution and reproduction in any medium or format, as long as you give appropriate credit to the original author(s) and the source, provide a link to the Creative Commons licence, and indicate if changes were made. The images or other third party material in this article are included in the article's Creative Commons licence, unless indicated otherwise in a credit line to the material. If material is not included in the article's Creative Commons licence and your intended use is not permitted by statutory regulation or exceeds the permitted use, you will need to obtain permission directly from the copyright holder. To view a copy of this licence, visit http://creativecommons.org/licenses/by/4.0/ The Creative Commons Public Domain Dedication waiver (http://creativecommons.org/publicdomain/zero/1.0/) applies to the data made available in this article, unless otherwise stated in a credit line to the data. 
Tobacco and alcohol consumption, sleep patterns, and protective sexual behaviors are also important targets of studies and interventions [7-10]. The behaviors associated with road safety, which prevent injuries and accidents, are also important and include avoiding traveling with someone who has drunk too much, driving within speed limits, and wearing seat belts. Some studies have also suggested a relationship between road accidents, alcohol, and substance consumption $[10,11]$. Besides, the use of drugs and medicines not prescribed by a physician, and the use of sedatives or amphetamines are closely associated with adverse consequences and with unhealthy growth patterns in adolescents [12-15].

Adolescence is a critical transitional period, but it is also the main phase in the development and construction of Social Skills (SS) of an emotional, physical, and health profile [16-19]. Moreover, having a good repertoire of SS is a well-known protective factor for health problems. In addition, healthy habits and risk behaviors are learned early in the life cycle [20] with SS being a positive predictor of a healthy lifestyle. Thus, the lack of SS has repercussions both on physical and socioemotional health, through the involvement in high-risk behaviors, which may lead to difficulties in adolescent development [16-19].

It is then essential to promote individual and social behaviors that can educate adolescents in their ability to make choices, especially if we consider the influence of the adolescents' lifestyle on the health and well-being in adulthood [21-23].

According to Del Prette and Del Prette [16], the family and the schools are the two main institutions and the contexts that have greater and direct responsibility for the integral development of adolescents. Additionally, the school has also a significant influence on the behavior and training of adolescents through the development of behaviors, abilities, and values influenced by peers [24, 25].

In sum, prevention and intervention in a school context should be highly prioritized in this population. Therefore, the main goals of this study are 1) to characterize Lifestyles and SS in a sample of Portuguese adolescents, and 2) to identify homogeneous subgroups (clusters) that allow the analysis of the behavioral profile of Lifestyles and SS, in order to promote a healthy lifestyle in this population, particularly in the group with the greatest need of being included in the skills-based health education programs.

\section{Methods}

\section{Study design and sample}

This is a cross-sectional study performed with adolescents attending schools in Portugal. Firstly, the Executive Boards of the five schools in the Tâmega and Sousa region were contacted to present the objectives and request authorization for the study. Written consent from the family was also required, as well as the authorization of the National Commission of Data Protection. A consent letter was sent home 2 weeks before the measurements. Students' participation was voluntary, and they were asked to give their verbal informed consent. Data collection took place between February and March of 2017. The questionnaires were administered by undergraduate nursing students. Regarding the guarantee of anonymity, the students were instructed not to write their names when completing the questionnaire, placing it afterward in a box placed in the room for that purpose. At the end of the data collection, the team members assigned a code for each questionnaire, which took, on average, 30 to $40 \mathrm{~min}$ to be completed. This study followed the ethical principles reported in the Helsinki Declaration and was approved by the Ethical Evaluation Committee of Cooperativa de Ensino Superior Politécnico e Universitário (CESPU), Porto, Portugal.

\section{Instruments}

A socio-demographic questionnaire, which included age, years of education, and school was used.

My Lifestyle Questionnaire (MLQ) [26]: assesses adolescents' lifestyle and was based on the Lifestyle Assessment Questionnaire of Hettler [27]. The My Lifestyle Questionnaire is comprised of 28 items answered according to a 5 -point Likert scale ( $1=$ " almost never" and 5 = "almost always") and contain five subscales: Physical Exercise (PE, e.g., "I walk or cycle daily"); Nutrition (NUT, e.g., "I avoid eating fatty foods"); Self-care (SFC, e.g., "I sleep enough hours to feel rested"); Monitored Safety (MS, e.g., "When I travel by car in the front seat, outside the city, I wear a seat belt); and Use of Drugs (UD, e.g., "I don't drink more than two alcoholic drinks a day"). The total scale ranges between 28 and 140, with the higher result indicating a healthier lifestyle. The total scale was transformed into a scale of $0-100 \%$. The Cronbach alpha in the original version was 0.76 for the total scale and 0.42 in Monitored Safety, 0.67 in Physical Exercise, 0.52 in Use of Drugs, 0.78 in Nutrition, and 0.67 in Self-care subscales. In the present study, the alpha for the total scale was 0.85 and 0.41 in Monitored Safety, 0.61 in Physical Exercise, 0.67 in Use of Drugs, 0.76 in Nutrition, and 0.77 in Self-care subscale.

The Social Skills Inventory (SSI) [28] assesses SS in adolescents and is comprised of 38 items, which evaluate the SS based on everyday situations of social interaction. Items are divided into six subscales skills: (1) Empathy (EMP, e.g., "When I notice that a colleague is in trouble, I offer my support"); (2) Assertiveness (ASS, e.g., "When a person makes a request that I find improper, I refuse"); (3) Self-control (SC, e.g., "I react calmly when things 
don't go as I wish"); (4) Civility (CIV, e.g., "When I'm leaving a place, I say goodbye to everyone"); (5) Affective Approach (AA, e.g., "When I want to date someone, I tell him/her at the first chance"); and (6) Social Development (SLD, e.g., "At school or in my job, I make oral presentations in groups when requested"). The items are based on a 5-points Likert scale: $0=$ " $0-2$ times", $1=$ " $3-4$ times", $2=$ "5-6 times", $3=$ "7-8 times", $4=$ "9-10 times", regarding the number of times the adolescent presents the indicated action or reaction. A higher result indicates a better SS repertoire. To minimize the social desirability effect, 15 out of 38 items were formulated in the negative sense. Data were converted into a percentile system for both the total scale and the subscales. In each percentile category, an interpretation defined by the authors was associated: category1: percentile between 01 and 25Below the lower average repertoire of SS; category2: percentile between 26 and 35- A lower average repertoire of SS; category3: percentile between 36 and 65- Good repertoire of SS; category4: percentile between 66 and 75Elaborate repertoire of Ss; and finally, category5: percentile between 76 and 100- Highly elaborate repertoire of SS. The Cronbach alphas in the Brazilian adolescent version [29] were the followings: Total Scale: 0.89; Empathy: 0.82; Self-control: 0.73; Civility: 0.75; Assertiveness: 0.68; Affective Approach: 0.70; Social Development: 0.61 . In this study, the alpha of the total scale was 0.95 and the alphas of the subscales were the following: Social Development: 0.64; Affective Approach: 0.73; Self-control: 0.77; Assertiveness: 0.80; Civility: 0.88; and Empathy: 0.90 .

\section{Data analysis}

Data analysis was based on descriptive, correlational, and classificatory statistics, supported by SPSS software version 24. Descriptive statistics (Mean/Standard Deviation) were used to characterize the sample and to present the descriptive values of the questionnaires. The total score of the SSI was calculated only for the adolescents who answered the 38 items and, therefore, only 442 adolescents were analyzed. Regarding OMEV, 431 participants were not analyzed for the same motive. Participants excluded from the analyses were different from the participants included in the analyses regarding gender $\left(\mathrm{X}_{(1)}^{2}=8.631, \quad p=.002\right)$ and age $\left(\mathrm{X}_{(1)}^{2}=15.17\right.$, $p<.001)$; that is, the group of participants excluded from the analyses was composed of more male students and younger ones, when compared to the group of participants who were included in the analyses. This makes sense because the items with the highest index of missing values are those dealing with sexual intercourse and substance use (see supplementary material).

Then, a Pearson correlation was performed, given the normality of the sample, in order to assess the relationship between Lifestyle and SS. To establish a profile of the participants, a Cluster Analysis (K-means) was applied considering the SSI percentiles of the total scale and subscales, as well as the total scale and subscales of the MLQ (considering a 0-100 scale \%). Kmeans is a simple clustering method used when there are unlabeled data (i.e., data without defined categories or groups). This is an iterative algorithm that tries to partition the data set into different predefined nonoverlapping subgroups (clusters), where each data point belongs to only one group. It brings together intracluster data points as similar as possible, while also keeping clusters as different (as far apart) as possible. Thus, the goal of this algorithm is to find groups in the data clustered based on feature similarity. To determine the optimal number of clusters two methods were used a direct method - the elbow and silhouette - and a statistical method through a specific library of $\mathrm{R}$ package. A $\mathrm{R}$ package fpc [30] was used that allows, through bootstrap resampling, to verify if the structure of the clustering solution remains, under admissible changes to the data set $[30,31]$. The optimal number of clusters depends on the method used for measuring similarities and the parameters used for partitioning. In this study, a solution of 3 clusters was adopted, being this the most adjusted to the results. The stability of the solution was tested by the Jaccard coefficient that measures the similarity or dissimilarity between two subjects. For the solution of three clusters, the average Jaccard index obtained is, for all clusters, greater than or equal to 0.95 (note: the closer to 1 the better). The analysis was performed using software $\mathrm{R}$ version 3.4.3. (package fpc). Kruskal-Wallis tests were used to analyze the differences in terms of sex and age. Finally, descriptive statistics (Mean and standard deviation) were mainly used to characterize the sample in cluster 2 because this was the one that most needed intervention in education and health promotion. A Pearson correlation was used to assess/evaluate the relationship between subscales and, finally, difference tests ( $T$ tests) were employed to verify any differences in gender and age in this cluster. The level of significance was set to 0.05 .

\section{Results}

\section{Sample characterization}

This study included 1008 adolescents attending the 7th to the 9th grade of five middle schools from the Tâmega and Sousa region of Portugal, with a mean age of 13.43 years $(\mathrm{SD}=1.1)$. The majority of the adolescents belonged to the group aged between 12 and 14 years $(85.2 \%)$, with the remaining $14.8 \%$ having between 15 and 17 years, homogeneously distributed by the 3 years of schooling (7th grade $=35.1 \%$, 8th grade $=33.6 \%$ and 
9th grade $=31.3 \%)$. Students $(n=556)$ who completed $98 \%$ of each questionnaire were included in the analysis.

Regarding Lifestyle, the total mean score was of $72.26 \%(0-100 \%$ scale), thus indicating a healthy Lifestyle. The Monitored safety subscale had a mean score of $65.69 \%$ while the subscale Nutrition had the lowest mean score, 59.97\%, however still higher than $50 \%$.

Concerning SS, the mean percentile was found to be 67.33 (corresponding to an overall mean score of 108.13). Half of the sample (50.7\%) showed a highly elaborated repertoire of SS, $11 \%$ an elaborate repertoire, $20.1 \%$ a good repertoire, and $2.7 \%$ a lower average repertoire of SS. Nevertheless, $15.5 \%$ of the students presented below the lower average repertoire of SS.

\section{Relationship between lifestyle and social skills subscales} Positive and significant relationships were found between the MLQ and SSI subscales (Table 1), indicating that adolescents with higher SS showed a healthy Lifestyle and vice versa.

\section{Cluster analysis}

Cluster 1, the "Adjusted" ( $n=92)$, corresponded to adolescents who had a less elaborate repertoire of SS, but with good indicators in all subscales of Lifestyle. In this cluster, students from categories 1 and 2 were included, i.e., those who presented results categorized as "below the lower average" and the "lower average of social skills" (see categories of percentiles defined in instruments section).

Cluster 2, the "Sociable" $(n=115)$ comprised adolescents with a good repertoire of SS Skills (category 3 of percentile) and with good indicators of Lifestyle, namely in the Physical Exercise, Self-care and Use of Drugs scales (although not as good as those in the cluster 1). However, this group showed poor Lifestyle indicators in Nutrition and Monitored Safety subscales.
Cluster $3(n=258)$, the "Healthy", included adolescents with an elaborate, but especially highly elaborate repertoire of SS (categories 4 and 5), and the best Lifestyle indicators (Fig. 1). In Fig. 1, observations are represented by points, through an analysis of principal components (APC), being represented according to the first two main components. Table 2 shows the sample number and the average values of the variables considered in each cluster.

\section{Differences in age and gender between clusters}

There were significant differences in age between clusters 1 and 2 , and clusters 2 and $3\left(\mathrm{X}_{(2)}^{2}=15.18, p<0.05\right)$, but there were no differences between clusters according to gender, i.e. the group of "Sociable" adolescents had a higher mean age than the groups of "Adjusted" and "Healthy" adolescents $(\mathrm{M}=14.0, \mathrm{SD}=1.12)$.

\section{Sample characterization of cluster 2, the "sociable"}

The group of "Sociable" adolescents included a majority of boys $(61.74 \%, n=71)$ with ages ranging between 12 and 14 years old $(70.43 \%, n=81)$. As it was possible to verify, the "Sociable" adolescents presented lower indicators in the subscales of Nutrition and Monitored Safety. By analysing these two subscales in detail (Table 3), the results showed that in the Monitored Safety subscale, item 13 was the one that presented the lowest value (MLQ13-"I do not drive (car, motorized, etc.) when I drink too much, or I do not travel with someone who drank too much", while in the Nutrition subscale, item 22 presented the lowest value (MLQ22-"I avoid eating foods that are made with sugar" (Table 3).

Relationship between the nutrition and monitored safety subscales and the social skills subscales

There was a positive and significant relationship between the Nutrition and the Civility subscales $(r=0.21, p<.01)$.

Table 1 Pearson's coefficient between the subscales of lifestyle and social skills questionnaires

\begin{tabular}{|c|c|c|c|c|c|c|c|c|c|c|c|}
\hline & 1. & 2. & 3. & 4. & 5. & 6. & 7. & 8. & 9. & 10. & 11. \\
\hline 1. SSI- Empathy & 1 & & & & & & & & & & \\
\hline 2. SSI- Self control & $.657^{* *}$ & 1 & & & & & & & & & \\
\hline 3. SSI- Civility & $.812^{* *}$ & $.567^{* *}$ & 1 & & & & & & & & \\
\hline 4. SSI- Assertiveness & $.784^{* *}$ & $.584^{* *}$ & $.704^{* *}$ & 1 & & & & & & & \\
\hline 5. SSI- Affective approach & $.684^{* *}$ & $.524^{* *}$ & $.524^{* *}$ & $.594^{* *}$ & 1 & & & & & & \\
\hline 6. SSI- Social development & $.703^{* *}$ & $.575^{* *}$ & $.596^{* *}$ & $.701^{* *}$ & $.587^{* *}$ & 1 & & & & & \\
\hline 7. MLQ- Physical Exercise & .016 & $.067^{*}$ & .052 & .030 & $.120^{* *}$ & $.195^{* *}$ & 1 & & & & \\
\hline 8. MLQ- Nutrition & $.080^{*}$ & $.157^{* *}$ & $.100^{* *}$ & $.069^{*}$ & $.072^{*}$ & $.104^{* *}$ & $.247^{* *}$ & 1 & & & \\
\hline 9. MLQ- Self-care & $.240^{* *}$ & $.217^{* *}$ & $.227^{* *}$ & $.228^{* *}$ & $.167^{* *}$ & $.230^{* *}$ & $.225^{* *}$ & $.403^{* *}$ & 1 & & \\
\hline 10. MLQ- Use of Drugs & $.252^{* *}$ & $.182^{* *}$ & $.212^{* *}$ & $.231^{* *}$ & $.111^{* *}$ & $.158^{* *}$ & $.144^{* *}$ & $.311^{* *}$ & $.603^{* *}$ & 1 & \\
\hline 11. MLQ- Monitored safety & $.123^{* *}$ & $.074^{*}$ & $.119^{* *}$ & $.154^{* *}$ & $.078^{*}$ & $.114^{* *}$ & $.153^{* *}$ & $.246^{* *}$ & $.337^{* *}$ & $.284^{* *}$ & 1 \\
\hline
\end{tabular}

SSI Social Skills Inventory, MLQ My Lifestyle Questionnaire, Pearson coefficient; ${ }^{*} p<.05 ;{ }^{* *} p<.01$ 


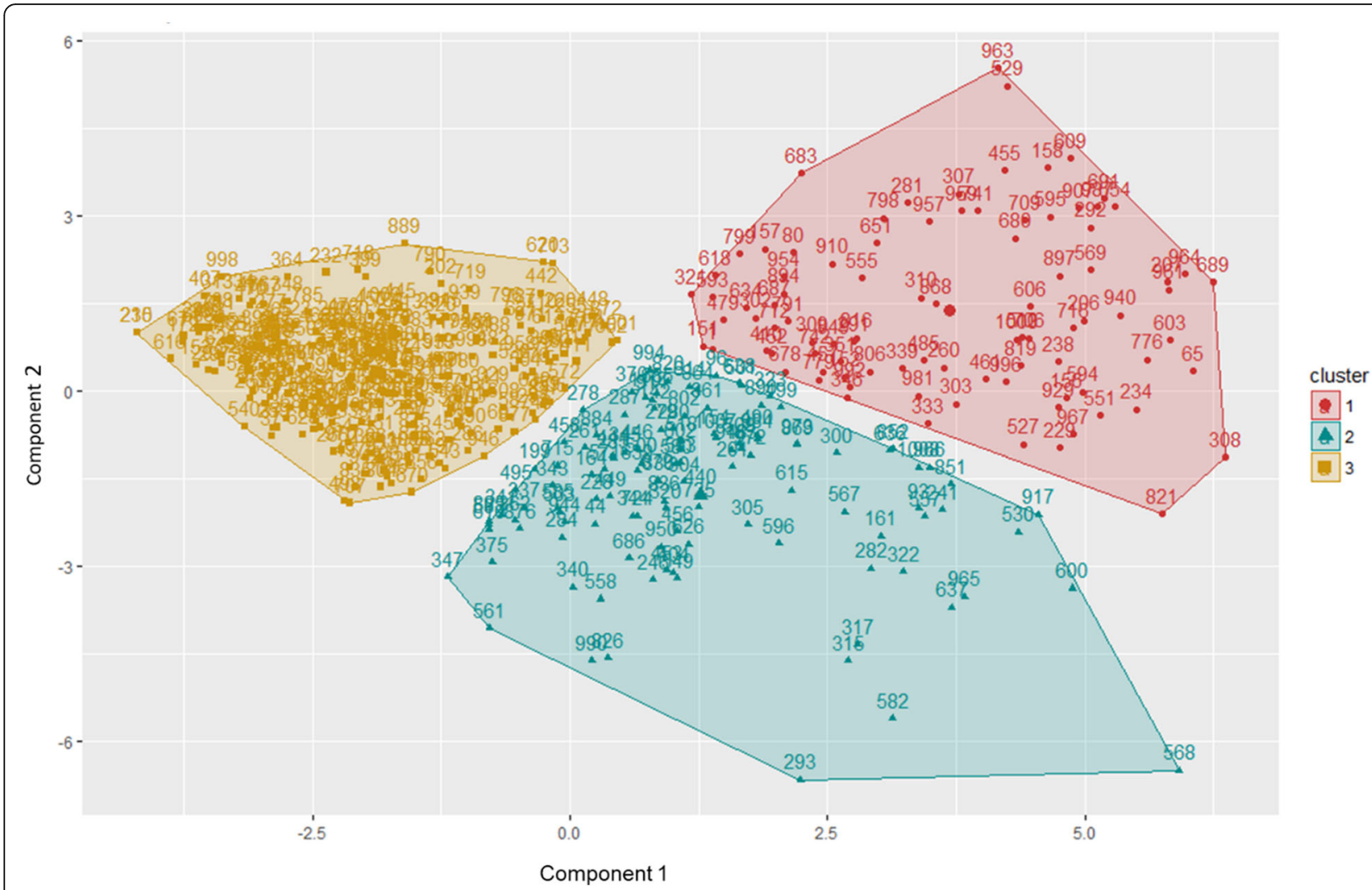

Fig. 1 K-means Clusters. Cluster $1(n=92)$ presented a less elaborate Social Skills repertoire, but with good indicators in all Lifestyle subscales - it was named "Adjusted" cluster. Cluster 2 ( $n=115)$ was formed by adolescents with good repertoire of Social Skills and good indicators of Lifestyle, but with poor Lifestyle indicators in the subscales Nutrition and Monitored Safety- it was called "Sociable". Cluster 3 ( $n=258)$ included adolescents with a highly elaborate repertoire of Social Skills and the best Lifestyle indicators - it was called a "Healthy" cluster

However, no significant relationships were found between the Monitored Safety and SS subscales.

\section{Gender and age differences in cluster 2, the "sociable"}

Significant gender differences were found in the subscale Physical Exercise $\left(t_{(86)}=2.55, p=.013\right)$, i.e. girls do less exercise compared with boys, yet no differences were found according to age.

\section{Discussion}

The results suggest that this sample of adolescents presents a healthy Lifestyle, assessed by the Lifestyle Questionnaire. Although higher than $50 \%$, the Monitored Safety and Nutrition subscales were the ones displaying a lower average score. Concerning SS, half of the sample presented a highly elaborate repertoire and, as the literature indicates and it was expected, the adolescents with the healthiest Lifestyle are those with improved SS resources [32]. Besides, a solution of three clusters was found with cluster 3, the "Healthy", being the largest one and cluster 2, the "Sociable", the one in most need of skills-based health education programs.
Regarding the Monitored Safety subscale, the item assessing if adolescents travel with someone who drank too much was the one that presented the lowest values $(\mathrm{M}=3.43, \mathrm{SD}=1.91$, ranging between 1 to 5$)$. This result may be related to the mean age of the current sample and not risk behavior. However, it is worth mentioning that in Portugal, the greatest occurrence of road accidents in motorized two-wheeled vehicles occurs mainly in male adolescents [33, 34] and, in the European Union, the highest prevalence of deaths has been observed in male adolescents between the ages of 15 and 29 years $[35,36]$. Moreover, one of the main causes of death and disability is alcohol consumption [35], and the injuries related to accidents or violent behaviors frequently associated with alcohol consumption are indicated as the major cause of death in childhood and adolescence (from 5 to 19 years) [34]. Although recent data suggested a decreasing trend in the prevalence of alcohol consumption in both sexes at age 15, it also implied an increase in 16-year-old female adolescents [37], emphasizing the urgent need to address this major cause of death and disability in adolescents, especially if associated with driving behaviors. Fortunately, according to 


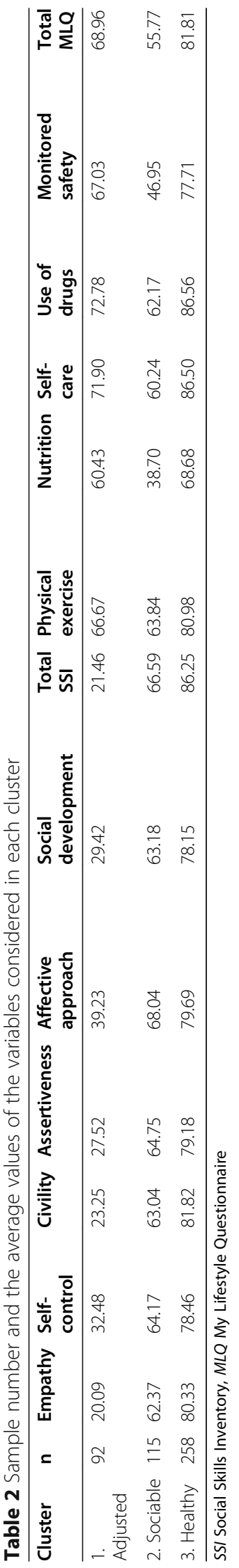


Table 3 Items descriptive measures of the Monitored Safety and Nutrition subscale

\begin{tabular}{|c|c|c|c|}
\hline & Minimum & $\begin{array}{l}\text { Mean } \\
\text { (SD) }\end{array}$ & Maximum \\
\hline \multicolumn{4}{|l|}{ Monitored Safety items } \\
\hline $\begin{array}{l}\text { MLQ .13: I do not drive (car, motorized, etc.) when I drink too much, or I do not travel with someone who drank } \\
\text { too much }\end{array}$ & 1.00 & $\begin{array}{l}3.43 \\
(1.91)\end{array}$ & 5.00 \\
\hline MLQ .14: When I drive, or when traveling in some vehicle, I like to stay within speed limits & 1.00 & $4.06(1.41)$ & 5.00 \\
\hline MLQ .15: When I drive in the front seat, out of town, I put the seat belt & 1.00 & $4.90(0.36)$ & 5.00 \\
\hline \multicolumn{4}{|l|}{ Nutrition items } \\
\hline MLQ .4: I am careful with what I eat so as to maintain the recommended weight for the height I have & 1.00 & $4.01(0.99)$ & 5.00 \\
\hline MLQ .5: I am careful with what I eat so as to reduce salt intake & 1.00 & $3.75(1.05)$ & 5.00 \\
\hline MLQ .6: I plan my diet so that it is balanced in nutrient variety & 1.00 & $\begin{array}{l}3.66 \\
(1.09)\end{array}$ & 5.00 \\
\hline MLQ .18: I avoid eating fat foods & 1.00 & $3.98(0.88)$ & 5.00 \\
\hline MLQ .22: I avoid eating foods that are made with sugar & 1.00 & $\begin{array}{l}3.45 \\
(1.09)\end{array}$ & 5.00 \\
\hline
\end{tabular}

MLQ My Lifestyle Questionnaire, SD Standard Deviation

the most recent results of the Health Behaviour in School-aged Children study in Portugal [33], from 6742 adolescents, most of them have never tried tobacco (93, $7 \%)$, rarely used alcohol (90\%) or drugs (96.1\%), and 88.2\% have reported never getting drunk.

Concerning Nutrition subscale, the item evaluating the consumption of foods with sugar had the lowest average score, highlighting that an increased proportion of adolescents does not avoid foods with sugar. These results are in line with the national scenario, as demonstrated in the Health Behavior in School-aged Children study, where more than half of the Portuguese adolescents who participated in the study reported consuming sweets and soft drinks at least once a week, and more than twothirds said that they sometimes ate unhealthy foods [3841]. Despite the encouraging results of the present study, which highlights a healthy Lifestyle in a representative sample of adolescents in the Tâmega and Sousa region, Nutrition/food and Monitored Safety still require greater investment in the implementation of skills-based health education programs, given the association of SS with Lifestyle (ranging between $\mathrm{r}=.07$ and $\mathrm{r}=.25$ with $p<.01$ and $p<.05)$.

Regarding the second aim of this study, the cluster analysis allowed the identification of three groups of adolescents with different behavior profiles. One of the clusters identified was named "Adjusted" because the adolescents here included showed less elaborate repertoire of SS, but good Lifestyle indicators. This group seems to have sufficient SS to adopt good and healthy behaviors. The second cluster was named "Sociable" because this group of adolescents showed high social abilities but some difficulties in adopting healthy and adequate Lifestyles, especially regarding Nutrition and Monitored
Safety, suggesting a protective effect of SS [32]. The third cluster was called "Healthy" because it was the group of adolescents displaying a highly elaborate repertoire of SS and with a healthier Lifestyle.

In addition, results also showed that the Nutrition subscale was related to Civility skills, suggesting that the promotion of this social competence can, in turn, increase health awareness and health behaviors, especially with regards to diet and nutrient planning. Interestingly, no significant relationships were found between the Monitored Safety subscale and SS. This result may be related to the age range of the sample since these adolescents did not have the legal age to drive yet ( $>18$ years old). However, among the Monitored Safety behaviors evaluated in the questionnaire used in the study ("When I travel by car, I put my seat belt; I did not travel with a driver who drank too much; When I travel with someone, I like to maintain speed limits"), not traveling with a driver who drank too much was the behavior reported with less frequency. It is also noteworthy that this group of adolescents, designated as "Sociable", was older than the group of adolescents in the "Adjusted" and "Healthy" clusters, but even so, ages ranged from 12 to 14 years old. Probably, the adolescents in this group are still too young to drive with friends. We also found that girls in this cluster practice less exercise when compared to boys, which is in agreement with the literature [9]. Knowing that levels of physical activity are below those recommended by WHO [40], this outcome emphasizes the need to promote the involvement of girls in physical activity. However, we did not find differences in Lifestyle according to age, which may be associated with the homogeneity of the sample (70\% of this cluster sample consists of adolescents between 12 and 14 years old). 


\section{Limitations and directions for future research}

This study has some limitations that should be pointed out. The instruments used were in a self-report format and anthropometric data of adolescents, while demographic data of parents (such as age, socioeconomic status, and household composition) were not collected. The study included only adolescents from the Tâmega and Sousa region, requiring a careful generalization of the findings. However, it is important to highlight that this region is characterized by a high prevalence of Tuberculosis [42], which, in addition to other factors, is also related to an unhealthy lifestyle [43].

For future studies, we suggest an assessment of adolescents and their parents, given the direct influence of parents' Lifestyle on their children's Lifestyle [44, 45]. Moreover, White and Halliwell [46] found that adolescents' perception of the mealtime environment contributes to the protective effect of family meals, i.e. family meals were significantly associated with a lower likelihood for alcohol and tobacco use. In addition, parental styles should be evaluated; especially the parental style of the mother, since literature has been suggesting that it influences the children's adoption of high-risk behaviors [47]. Screen time consumption is also an important concern, given its association with a reduced level of physical activity [48], and so future studies should control for this variable. Several studies have demonstrated an advantage in the use of text messages, internet programs, and chats, apps (e.g. WhatsApp), as effective tools to instigate behavior changes in adolescents $[49,50]$. This is, in fact, a controversial topic that needs further research.

\section{Implications for practice}

This study reveals some implications for practice. Concerning the sample under study, we suggest regular health education sessions mainly focused on sugar intake behaviors, meal planning, and travel safety with a driver who drinks too much (i.e. Social Skills training), as well as promoting the involvement of girls in the practice of physical activity. Given that previous behavior is the best predictor of the intentions to adopt healthy behaviors, namely having a balanced diet, practicing sports, not drinking alcohol, and not smoking or taking drugs [51], we suggest that health education sessions should be strongly implemented in the school context [52, 53]. Nonetheless, there are several activities more attractive for girls that could also be included in the physical activity curriculum, rather than football or volleyball. The promotion of a healthy lifestyle should be included in the school curriculum and be transversal to all academic disciplines.

In general, health education sessions should include factors that protect the adoption of risk behaviors, engage the main contexts of adolescent life, and address various health behaviors and target risks $[38,54]$. The school context is privileged to carry out actions of this nature, but the inclusion and involvement of both adolescents and parents become fundamental. The promotion of an available repertoire of SS that educates adolescents to a competent social style in Lifestyle choices is essential $[55,56]$. Moreover, supporting emotional regulation, as well as adaptive coping strategies, is crucial for health promotion, especially in this population [57]. For example, self-regulation cognitions are positively related to healthy eating in adolescents [58]. Managing emotional regulation during class, conflict resolution, decision making, and choice may help adolescents in the adoption of healthy and protection behaviors. The most recent report of the Health Behaviour in School-aged Children study in Portugal [33] recommends the continuation of adolescent health programs, including sex education in schools, higher age limits for alcohol consumption, and obligatory use of seat belts and helmets, aiming to promote healthier lifestyles in adolescents, prevent deaths and disability.

\section{Conclusions}

This was the first study focused on the relationship between lifestyle and SS in Portuguese adolescents, which identified adolescents at risk of having an unhealthy Lifestyle by using short questionnaires and a simple cluster analysis technique. In general, the adolescents in this sample revealed a healthy lifestyle and a highly elaborated repertoire of SS. The "Healthy" cluster was the largest in the sample and was composed of adolescents with highly elaborated SS and good indicators of a healthy lifestyle. Besides, the results emphasize that the students included in the group called "Sociable" are the ones that need to be most included in skills-based health education programs. Nutrition and Monitored Safety behaviors displayed low values and, therefore, present a greater need for awareness, sensitization, and intervention in the school context. In conclusion, the promotion of a healthy lifestyle should be part of the academic curriculum and be transversal to all academic disciplines.

\section{Supplementary Information}

The online version contains supplementary material available at https://doi. org/10.1186/s12889-021-10355-1.

\section{Additional file 1.}

\section{Abbreviations}

LS: Lifestyle; MLQ: My Lifestyle Questionnaire; SSI: Social Skills Inventory; SS: Social Skills; EMP: Empathy; SC: Self-control; CIV: Civility;

ASS: Assertiveness; AA: Affective Approach; SLD: Social Development; PE: Physical Exercise; NUT: Nutrition; SFC: Self-care; UD: Use of Drugs; MS: Monitored Safety. 


\section{Acknowledgments}

The authors gratefully acknowledge the contributions of all participants in this study and the CESPU, Institute of Research and Advanced Training in Health Sciences and Technologies for funding the study.

\section{Authors' contributions}

All authors were responsible for the data collection. CM, SL, SP, and RE conceived and designed the study. TH, GS, and LA performed the statistical analysis. AN, FR, and SP wrote the first draft of the manuscript, and RE, CM and SL were responsible for the several revisions of the manuscript. SP, SL, $R E, F R$, and CM provided critical comments and joined other authors in revising the manuscript and approving the final submission. All authors have read and approved the manuscript in its current form. All authors approved the final manuscript and $\mathrm{CM}$ is the guarantor.

\section{Funding}

This study was financially supported by the CESPU_Institute of Research and Advanced Training in Health Sciences and Technologies (Reference PCERTSPTF-IINFACTS-2019). The publication costs for this article have been funded by a grant from the publication fund of the CESPU_Institute of Research and Advanced Training in Health Sciences and Technologies.

\section{Availability of data and materials}

The dataset used during the current study is available from the corresponding author by reasonable request.

\section{Ethics approval and consent to participate}

According to national regulations, the study is registered, authorized, and funded by the Ethical Evaluation Committee of Cooperativa de Ensino Superior Politécnico e Universitário (CESPU), Porto, Portugal and was also registered in the Portuguese Data Protection Agency ( $\left.N^{\circ} 13764 / 2015 ; 1877\right)$, Portugal. The Principal Researcher contacted the Executive Boards of the five schools in the Tâmega and Sousa region in order to present the objectives and to request authorization for the study from the Portuguese National Agency of Education ( $N^{\circ} 0508300002$ ). After obtaining the authorizations, written informed consent was signed by the adolescents' parents. This study followed the ethical principles reported in the Helsinki Declaration.

\section{Consent for publication}

Not applicable.

\section{Competing interests}

The authors declare that they have no competing interests.

\section{Author details}

${ }^{1}$ CESPU, Institute of Research and Advanced Training in Health Sciences and Technologies, Rua Central de Gandra, 1317, 4585-116 Gandra, PRD, Portugal. ${ }^{2}$ University Institute of Maia (ISMAI), Castelo da Maia, Portugal. ${ }^{3}$ Research Center in Physical Activity, Health and Leisure (CIAFEL), Porto, Portugal. ${ }^{4}$ High School Augusto Gomes, Matosinhos, Porto, Portugal. ${ }^{5}$ Research Center in Sports Sciences, Health and Human Development (CIDESD), Maia, Portugal. ${ }^{6}$ Department of Medical Sciences, Institute of Biomedicine - iBiMED, University of Aveiro, Aveiro, Portugal.

Received: 14 December 2019 Accepted: 28 January 2021 Published online: 18 February 2021

\section{References}

1. Park MJ, Scott JT, Adams SH, Brindis CD, Irwin CE Jr. Adolescent and young adult health in the United States in the past decade: little improvement and young adults remain worse off than adolescents. J Adolesc Health. 2014;55: 3-16.

2. WHO: Improving adolescent health and development. Department of Child and Adolescent Health and Development Family and Community Health. [Accessed 11 Nov 2019]. 2001. Available from: http://apps.who.int/iris/ bitstream/handle/10665/43458/9789241594226_eng.pdf;jsessionid=3F0D4 979735D652EFEE325725A48B634? sequence $=1$

3. Center for Disease Control and Prevention. U.S. Department of Health and Human Services: Office of Disease Prevention and Health Promotion-
Healthy People 2010 [Accessed: 10 Sept 2019]. Available from: https://www. cdc.gov/nchs/healthy_people/hp2010.htm

4. Aires L, Silva P, Santos R, Santos P, Ribeiro JC, Mota J. Association of physical fitness and body mass index in youth. Minerva Pediatr. 2008;60:397-405.

5. Andersen LB, Riddoch C, Kriemler S, Hills A. Physical activity and cardiovascular risk factors in children. Br J Sports Med. 2011;45:871-6.

6. Sardinha LB, Santos R, Vale S, Silva AM, Ferreira JP, Raimundo AM, et al. Prevalence of overweight and obesity among Portuguese youth: a study in a representative sample of 10-18-year-old children and adolescents. Int J Pediatr Obes. 2011;6:124-8.

7. Felton G, Parsons MA, Ward DS, Pate RR, Saunders RP, Dowda M, et al. Tracking of avoidance of alcohol use and smoking behavior in a fifth-grade cohort over three years. Public Health Nurs. 1999;16:32-40.

8. Hoffman JH, Welte JW, Barnes GM. Co-occurrence of alcohol and cigarette use among adolescents. Addict Behav. 2001;26:63-78.

9. Tassitano RM, Dumith SC, Chica DA, Tenório MC. Aggregation of the four main risk factors to non-communicable diseases among adolescents. Revista Brasileira de Epidemiologia. 2014;17:465-78.

10. White A, Hingson R. The burden of alcohol use: excessive alcohol consumption and related consequences among college students. Alcohol Res. 2013;35:201-18.

11. Mercer $\mathrm{CH}$, Tanton $\mathrm{C}$, Prah $\mathrm{P}$, Erens B, Sonnenberg P, Clifton S, et al. Changes in sexual attitudes and lifestyles in Britain through the life course and over time: findings from the National Surveys of sexual attitudes and lifestyles (Natsal). Lancet. 2013;382:1781-94.

12. Bogstrand ST, Gjerde H, Normann PT, Rossow I, Ekeberg O. Alcohol, psychoactive substances and non-fatal road traffic accidents-a case-control study. BMC Public Health. 2014;12:734.

13. Fonseca AC. Consumo de álcool e seus efeitos no desempenho escolar [alcohol consumption and its effects on school performance]. Revista Portuguesa de Pedagogia. 2010;44:259-79.

14. Heim J, Andrade A. Efeitos do uso do álcool e das drogas ilícitas no comportamento de adolescentes de Risco: uma revisão das publicações científicas entre 1997 e 2007 [effects of alcohol and illicit drug use on adolescent risk behavior: a review of scientific publications between 1997 and 2007]. Revista de Psiquiatria Clínica. 2008:35:61-4.

15. Tavares T, Bonito J, Oliveira MM. O consumo de álcool pelos jovens dos ensinos básico e secundário no distrito de Beja: contributo para a definição de um projecto de prevenção seletiva. In: Pereira BO, Carvalho GS, editors. Atas do VII Seminário Internacional de Educação Física, Lazer e Saúde. IVII International Seminar on Physical Education, Leisure and Health]. Braga, Portugal: Center for Research in Children's Studies, Institute of Education, University of Minho; 2011. p. 1657-69.

16. Del Prette A, Del Prette ZAP. Treinamento de habilidades sociais na escola: o método vivencial e a participação do professor. In: Bandeira M, Del Prette ZAP, Del Prette A, editors. Estudos sobre habilidades sociais e relacionamento interpessoal [studies on social skills and interpersonal relationships]. São Paulo: Casa do Psicólogo; 2006.

17. Del Prette ZAP, Del Prette A. Habilidades sociais: Uma área em desenvolvimento [Social Skills: A developing área]. Psicologia Reflexão e Crítica. 1996:9:233-55.

18. Del Prette ZAP. Del Prette a Psicologia das relações interpessoais e habilidades sociais: vivências Para o trabalho em grupo [psychology of interpersonal relations and social skills: experiences for group work]. Editora Vozes: Petrópolis; 2000.

19. Del Prette ZAP, Del Prette A. Psicologia das habilidades sociais na infância: Teoria e prática [psychology of social skills in childhood: theory and practice]. Vozes: Petrópolis; 2005.

20. Murphey D, Mackintosh B, McCoy-Roth M. Early childhood: highlights. Child Trends. 2011;2:1-9.

21. Kelly SA, Melnyk BM, Jacobson DL, O'Haver JA. Correlates among healthy lifestyle cognitive beliefs, healthy lifestyle choices, social support, and healthy behaviors in adolescents: implications for behavioral change strategies and future research. J Pediatr Health Care. 2011;25:216-23.

22. Telama R, Yang X, Vikari J, Valimaki I, Wanne O, Raitakari O. Physical activity from childhood to adulthood: a 21-year tracking study. Am J Prev Med. 2005;28:267-73.

23. Turagabeci AR, Nakamura K, Takano T. Healthy lifestyle behaviour decreasing risks of being bullied, violence, and injury. PLoS One. 2008;3:e1585.

24. Beauchamp $M$, Anderson V. An integrative framework for the development of social skills. Psychol Bull. 2010;136:39-64. 
25. Wentzel K. Social competence, sociocultural contexts, and school success. In: Gottfried A, editor. Academic motivation and the culture of the school in childhood and adolescent. New-York: Oxford University Press; 2008.

26. Pais-Ribeiro JL. Avaliação das intenções comportamentais relacionadas com a promoção e proteção da saúde e com a prevenção das doenças [Assessment of behavioral intentions related to health promotion and protection and disease prevention]. Análise Psicológica. 2004;2:387-97.

27. Hettler B. Wellness promotion and risk reduction on university campus. In: Faber MM, Reinhardt AM, editors. Promoting health through risk reduction. New York: Collier Macmillan Publishers; 1982. p. 207-38.

28. Del Prette A, Del Prette ZAP. Inventário de habilidades sociais (IHSDelPrette): manual de aplicação, apuração e interpretação [social skills inventory (IHS-Del Prette): handbook of aplication, assessment and interpretation]. Casa do Psicólogo: São Paulo; 2001.

29. Del Prette A, Del Prette ZAP. Inventário de habilidades sociais Para adolescentes (IHSA-Del-Prette): manual de aplicação, apuração e interpretação [social skills inventory for adolescents (IHSA-Del Prette): handbook of aplication, assessment and interpretation]. São Paulo: Casa do Psicólogo; 2009.

30. Hennig C. Cluster-wise assessment of cluster stability. Computational Statistics and Data Analysis. 2007;52:258-71.

31. Hennig C. Package 'fpc' - flexible procedures for clustering (version 2.1-11); 2018.

32. Del Prette A, Del Prette ZAP. Habilidades sociais e análise do comportamento: proximidade histórica e atualidades [social skills and behavioral analysis: historical proximity and current events]. Revista Perspectivas. 2010;1:104-15.

33. Matos MG, Equipa Aventura Social. A saúde dos adolescentes portugueses após a recessão [The health of Portuguese adolescents after the recession] Relatório do estudo Health Behaviour in School Aged Children (HBSC) em 2018 (ebook).[Accessed 11 Sept 2019]. 2018 Available from: www. aventurasocial.com

34. Puga P. Sinistralidade rodoviária: Saúde e Condutas de Risco. In: Ferreira VS, Barrisco B, Fernandes AM, Puga P, Vieira J, editors. A Condição Juvenil Portuguesa na Viragem do Milénio. Um Retrato longitudinal através de Fontes Estatísticas Oficiais: 1990-2005 [the Portuguese youth condition at the turn of the millennium. A longitudinal portrait from official statistical sources: 1990-2005]. Lisboa: Instituto Português da Juventude; 2006.

35. WHO. Global status report on alcohol and health. 2011. [Accessed at 11 Sept 2019). Available from: https://www.who.int/substance_abuse/ publications/global_alcohol_report/msbgsruprofiles.pdf

36. Mackay M, Vincenten J. Child safety report card 2012: Europe summary for 31 countries. European Child Safety Alliance, Eurosafe: Birmingham; 2012.

37. Precioso J, Correia C, Sousa I, Samorinha C. Evolução do consumo de álcool em adolescentes portugueses escolarizados: beber álcool ainda estará na moda? [Evolution of alcohol consumption in Portuguese school adolescents: is drinking alcohol still in fashion?]. Interações. 2015;39:802-14.

38. Matos MG. Equipa do Projecto Aventura Social. A saúde dos adolescentes portugueses (Quatro anos depois). [Project Team Socia Adventure. The health of Portuguese adolescents (Four years later)]. Lisboa: Edições FMH; 2003.

39. Matos MG. Equipa do Projeto Aventura Social e Saúde. A saúde dos Adolescentes portugueses (quatro anos depois) [Project Team Socia Adventure. The health of Portuguese adolescents (Four years later)]. Relatório Português Estudos HBSC. Edições FMH: Lisboa; 2014.

40. Matos MG, Marques A, Calmeiro L, Loureiro N. Diferentes perfis comportamentais em adolescentes e associação à prática de atividade física [different behavioral profiles in adolescents and association with the practice of physical activity]. Psicologia, Saúde \& Doenças. 2014;15:495-509.

41. Matos MG, Simões C, Carvalhosa SF, Reis C. A saúde dos adolescentes portugueses: Estudo nacional da rede europeia HBSC/OMS (1998) [The health of Portuguese adolescents: A national study of the European network HBSC/WHO (1998)]. Lisboa: Edições FMH; 2000.

42. Moreira R. Penafiel, Região com a maior incidência de tuberculose sem pneumologistas [Penafiel, Region with the highest incidence of tuberculosis without pulmonologists]. 2008. [Accessed 10 July 2018]. Available from: https://www.jn.pt/local/noticias/porto/penafiel/interior/regiao-com-a-maiorincidencia-de-tuberculose-sem-pneumologistas-9078264.html

43. Rodrigues G. Tuberculose uma doença social. Estudo casuístico em internamento hospitalar [Tuberculosis a social disease. Casuistic study in hospital admission]. 2018. Available from: http//www.elsevier.pt/pt/revistas/ revista-portuguesa-pneumologia-420/pdf/S0873215915307509/S350/

44. Ahlburg D. Intergenerational transmission of health. Am Econ Rev. 1998;88: 265-70.

45. Trannoy A, Tubeuf S, Jusot F, Devaux M. Inequality in opportunities in health in France: a first pass. Health Econ. 2010;19:921-38.

46. White J, Halliwell E. Alcohol and tobacco use during adolescence. The importance of the family mealtime environment. J Health Psychol. 2010;15: 526-32.

47. Paiva FS, Bastos RR, Ronzani TM. Parenting styles and alcohol consumption among Brazilian adolescents. J Health Psychol. 2012;17:1011-21.

48. Anez E, Fornieles-Deu A, Fauquet-Ars J, Lopez-Guimera G, Punti-Vidal J, Sanchez-Carracedo D. Body image, dissatisfaction, physical activity and screen-time in Spanish adolescents. J Health Psychol. 2016;23:36-47.

49. Chassiakos YR, Radesky J, Christakis D, Moreno MA, Cross C. Council on communications and media (2016). Children and adolescents and digital media. Pediatrics. 2016;138:e20162593.

50. Silva C, Fassnacht DB, Ali K, Gonçalves S, Conceição E, Vaz A, Criosby RD, Machado PP. Promoting health behaviour in Portuguese children via short message service: the efficacy of a text-messaging programme. J Health Psychol. 2015;20:806-15.

51. Simões C, Marques J. Determinantes sócio-cognitivas de intenções comportamentais relacionadas com a saúde [socio-cognitive determinants of behavioral intentions related to health]. Revista de Educação Especial e Reabilitação. 2000;7:25-36.

52. Durlak JA, Taylor RD, Kawashima K, Pachan MK, Dupre EP, Celio Cl, Berger SR, Dymnicki AB, Weissberg RP. Effects of positive youth development programs on school, family, and community systems. Am J Community Psychol. 2007;39:269-86.

53. Durlak JA, Weissberg RP, Dymnicki AB, Taylor RD, Schellingeer KB. The impact of enhancing students' social and emotional learning: a metaanalysis of school-based universal interventions. Child Dev. 2001;82:405-32.

54. Simões C. Comportamentos de risco na adolescência [Adolescent risk behaviors]. Lisboa: Fundação Calouste Gulbenkian e Fundação para a Ciência e a Tecnologia; 2007

55. Murta SG, Borges FA, Ribeiro DC, Rocha EP, Menezes JCL, Prado MM. Prevenção primária em saúde na adolescência: avaliação de um programa de habilidades de vida [Primary prevention in adolescent health: evaluation of a life skills program]. Estud Psicol. 2009;14:181-9.

56. Simões C, Matos MG. Promoção das competências sociais como estratégia de facilitação do desenvolvimento pessoal e social [promotion of Social Skills as a strategy for the facilitation of personal and social development]. Revista Educação Especial e Reabilitação. 1994;2:47-56.

57. Horn AB, Possel $P$, Hautzinger M. Promoting adaptive emotion regulation and coping in adolescence: a school-based Programme. J Health Psychol. 2011;16:258-73 Kalava TV, Maes S, De Gucht V. Interpersonal and selfregulation determinants of healthy and unhealthy eating behavior in adolescents. J Health Psychol 2010;15:44-52.

58. Kalava TV, Maes S, De Gucht V. Interpersonal and self- regulation determinants ofhealthy and unhealthy eating behavior in adolescents. J Health Psychol. 2010;15:44-52.

\section{Publisher's Note}

Springer Nature remains neutral with regard to jurisdictional claims in published maps and institutional affiliations.

\section{Ready to submit your research? Choose BMC and benefit from:}

- fast, convenient online submission

- thorough peer review by experienced researchers in your field

- rapid publication on acceptance

- support for research data, including large and complex data types

- gold Open Access which fosters wider collaboration and increased citations

- maximum visibility for your research: over $100 \mathrm{M}$ website views per year

At BMC, research is always in progress.

Learn more biomedcentral.com/submissions 